\title{
Kompetensi Guru Bahasa Indonesia di SMP Negeri Simpang Kosgoro Kabupaten Musi Rawas
}

\author{
Komiah $^{* 1}$, Suhartono ${ }^{2}$, Gumono $^{3}$ \\ Program Magister Pendidikan Bahasa Indonesia, Universitas Bengkulu ${ }^{1,2,3}$ \\ Corresponding email: komiahomah7@gmail.com
}

\begin{abstract}
The purpose of this study was to describe the competence of Indonesian language teachers in Indonesian language learning at SMP Negeri Simpang Kosgoro, Muasi Rawas Regency. This research is a quantitative descriptive research. The collection technique uses observation and questionnaires. The data analysis technique was carried out by data reduction, data classification, data interpretation, and conclusions. Wetness test data using membercheck. The results showed that the performance competence of Indonesian civil servant teachers in the National Education Office of Musi Rawas Regency from pegagogical competence, personality competence, social competence, and professional competence, especially in SMP Negeri Simpang Kosgoro showed that it had reached a value range of $75-100$ with value 4 in the very good category.
\end{abstract}

Keywords: Indonesian teacher competence, teacher performance appraisal

\begin{abstract}
Abstrak
Tujuan penelitian ini adalah untuk mendeskripsikan kompetensi guru bahasa Indonesia dalam pembelajaran bahasa Indonesia di SMP Negeri Simpang Kosgoro Kabupaten Muasi Rawas. Penelitian ini termasuk jenis penelitian deskriptif kuantitatif. Teknik pengumpulan menggunakan teknik observasi dan kuesioner. Teknik analisis data dilakukan dengan reduksi data, klasifikasi data, interpretasi data, dan kesimpulan. Uji kebasahan data menggunakan membercheck. Hasil penelitian menunjukkan bahwa kompetensi kinerja guru pegawai negeri sipil Mata Pelajaran Bahasa Indonesia di lingkungan Dinas Pendidikan Nasional Kabupaten Musi Rawas dari kompetensi pegagogik, kompetensi kepribadian, kompetensi sosial, dan kompetensi profesional khususnya di SMP Negeri Simpang Kosgoro menunjukkan sudah mencapai nilai rentang 75-100 dengan nilai 4 dengan kategori sangat baik.
\end{abstract}

Kata kunci: kompetensi guru bahasa Indonesia, penilaian kinerja guru

\section{PENDAHULUAN}

Proses pendidikan adalah proses transformasi atau perubahan kemampuan potential individu peserta didik menjadi kemampuan nyata untuk meningkatkan taraf hidupnya lahir dan batin (Susanti, 2013). Peran guru yang profesional dalam hal ini menjadi penting dalam mewujudkan hal itu. Sebagai guru profesional hendaknya harus mengerti keadaan dan kondisi siswa, karena hal ini merupakan salah satu 
dasar untuk menentukan metode pembelajaran yang akan diterapkan di kelas (Rivalina, 2016). Selain mempertimbangkan kondisi siswa, guru juga harus memperhatikan bahan pelajaran serta sumber-sumber belajar yang akan dipergunakan (Noermanzah, 2015). Motivasi dan semangat juga hendaknya dimiliki oleh guru untuk selalu membuat inovasi dan pembaharuan dalam proses pembelajaran (Sagala, 2006). Untuk mewujudkan guru yang profesioal, guru harus memiliki kompetensi yang melekat padanya karena guru sebagai sebuah profesi.

Sarimaya (2009) dan Muspawi (2020) menjelaskan kompetensi guru merupakan seperangkat pengetahuan, keterampilan, dan perilaku yang harus dimiliki, dihayati, dikuasai, dan diimplementasikan oleh guru dalam melaksanakan tugas keprofesionalannya. Bentuk komptensi guru ditampilkan melalui unjuk kerjanya dalam menjalankan tugasnya di sekolah (Damanik, 2019). Lebih lanjut dijelaskan bahwa komptensi guru merupakan gambaran hakiki kualitatif dari perilaku guru atau tenaga pendidik yang tampak sangat berarti dalam mengembangkan dan mencapai tujuan pembelajaran (Uno, 2009).

Perilaku guru di sini merujuk bukan hanya pada perilaku nyata, tetapi juga meliputi hal-hal yang tidak tampak. Kompetensi atau kemampuan merupakan perilaku yang rasional untuk mencapai tujuan yang dipersyaratkan sesuai dengan kondisi yang diharapkan dimana guru itu berada. Dapat disimpulkan kompetensi guru adalah kapasitas internal yang dimiliki guru dalam melaksanakan tugas profesinya.

Dalam Undang-Undang Republik Indonesia No. 142005 tentang Guru dan Dosen dan Peraturan Pemerintah No. 19 Tahun 2005 dinyatakan bahwa kompetensi guru meliputi kompetensi keperibadian, pedagogik, profesional, dan sosial. Keempat kompetensi guru tersebut dalam praktiknya merupakan satu kesatuan yang utuh (holistik) yang dapat diperoleh melalui pendidikan akademik sarjana atau diploma empat, pendidikan profesi ataupun melalui pembinaan dan pengembangan profesi guru (Ananda, 2017). Kompetensi merupakan modal yang amat penting bagi seorang guru dalam melakanakan tugas keprofesionalannya. Untuk itu, apabila ingin melihat sejauh mana kompetensi yang dimiliki guru kita bisa melihat hasil penilaian kinerja (PK) guru.

Pelaksanaan penilaian kinerja (PK) guru dimaksudkan bukan untuk menyulitkan guru, tetapi sebaliknya PK Guru dilaksanakan untuk mewujudkan guru yang profesional, karena harkat dan martabat suatu profesi ditentukan oleh kualitas layanan profesi yang bermutu. Menemukan secara tepat tentang kegiatan guru di dalam kelas, dan membantu mereka untuk meningkatkan pengetahuan dan keterampilannya, akan memberikan kontribusi secara langsung pada peningkatan kualitas pembelajaran yang dilakukan, sekaligus membantu pengembangan karier guru sebagai tenaga profesional (Ahmad, 2017). Oleh karena itu, untuk meyakinkan bahwa setiap guru adalah seorang profesional di bidangnya dan sebagai penghargaan atas prestasi kerjanya, maka PK Guru harus dilakukan terhadap guru di semua satuan pendidikan formal yang diselenggarakan oleh pemerintah, pemerintah daerah, dan masyarakat. Guru yang dimaksud tidak terbatas pada guru yang bekerja di satuan pendidikan di bawah kewenangan Kementerian Pendidikan Nasional, tetapi juga mencakup guru yang bekerja di satuan pendidikan di lingkungan Kementerian Pendidikan Nasional.

Manajemen kinerja, juga merupakan sebuah pendekatan dalam pengelolaan dan pengembangan sumber daya manusia dalam upaya meningkatkan jenjang karier dalam jangka panjang dan untuk pengembangan organisasi (Putri \& Imaniyati, 
2017). Salah satu bentuk dari manajemen kinerja adalah performance appraisal (penilaian kinerja individu) yang merupakan sistem yang digunakan manajemen untuk mengevaluasi kinerja individu dalam periode tertentu, memberikan feedback dan membina individu sehingga setiap individu diharapkan dapat meningkatkan kinerjanya. Peningkatan kinerja individu tentunya akan meningkatkan kinerja organisasi.

Hasil PK Guru dapat dimanfaatkan untuk menyusun profil kinerja guru sebagai input dalam penyusunan program Pengembangan Keprofesian Berkelanjutan (PKB) (Rusnailah, 2019). Hasil PK Guru juga merupakan dasar penetapan perolehan angka kredit guru dalam rangka pengembangan karier guru sebagaimana diamanatkan dalam Peraturan Menteri Negara Pendayagunaan Aparatur Negara dan Reformasi Birokrasi Nomor 16 Tahun 2009 tentang Jabatan Fungsional Guru dan Angka Kreditnya. Jika semua ini dapat dilaksanakan dengan baik dan obyektif, maka citacita pemerintah untuk menghasilkan insan yang cerdas dan berdaya saing tinggi lebih cepat direalisasikan.

Keberhasilan penguasaan kompetensi, menuntut adanya beberapa faktor yang harus dipenuhi baik oleh guru, maupun pihak pengelola dalam hal ini pihak sekolah. Untuk itu, maka seorang guru dituntut memiliki kemampuan dalam menggunakan metode pembelajaran yang efektif sehingga mampu mengajarkan dan menstransfer kompetensi yang diharapkan kepada siswa. Untuk dapat menguasai kompetensi di mata pelajaran ini maka guru disamping harus memiliki kemampuan yang bersifat akademis, mereka juga harus memiliki sikap disiplin, teliti, telaten, percaya diri, mampu bekerja sama dalam tim, serta memiliki daya analisis yang kuat. Namun dalam kenyataan yang dijumpai di beberapa sekolah beberapa tahun terakhir ini mengalami kemunduran, baik dalam kemampuan akademis maupun sikap mahasiswa.

Proses pembelajaran bahasa Indonesia, sikap guru jauh dari yang semestinya dijalankan. Masih banyak dijumpai guru yang kurang disiplin, yaitu sering datang terlambat dan dalam membuat sketsa tidak sesuai dengan prosedur yang benar atau tanpa memperhatikan sumber ide sebagai acuan. Sifat teliti dan ketelatenan guru masih sangat kurang, hal ini terlihat jelas dari media ajar memilki dimensi yang menyimpang jauh dari yang semestinya. Disamping beberapa hal tersebut, kemampuan akademis guru ternyata $70 \%$ masih termasuk dalam kategori rendah.

Salah satu usaha kepala sekolah untuk meningkatkan kompetensi profesional tenaga pendidik di lembaga pendidikan negeri dan swasta, yaitu memberikan waktu mengajar kepada guru minimal 24 jam pelajaran per minggu sesuai dengan keahliannya (sesuai dengan latar belakang pendidikan yang ditekuninya). Pemberian jam mengajar tersebut menuntut agar guru memiliki kualifikasi pendidikan dan bidang ilmu sesuai dengan mata pelajaran yang diajarkannya.

Pada kenyataannya usaha kepala sekolah tersebut memang mendapat pro dan kontra di kalangan pendidik. Namun terlepas dari itu, peneliti beranggapan bahwa usaha kepala sekolah itu tidak akan sulit dilaksanakan di satuan pendidikan tingkat SMP. Tenaga pendidik SMP sudah berlatar belakang pendidikan minimum S1 dan sesuai dengan mata pelajaran yang diajarkannya.

Bahasa Indonesia merupakan salah satu dari mata pelajaran yang menjadi tujuan utama seseorang dalam mempelajari bahasa. Kemampuan lainnnya adalah menyimak, berbicara, dan membaca. Berbeda dengan keterampilan berbahasa lainnya, keterampilan menulis lebih rumit dan kompleks karena terkait dengan 
beberapa kaidah yang harus diperhatikan, bahkan melibatkan semua keterampilan berbahasa.

Bila siswa dituntut untuk mampu berbahasa Indonesia dengan baik, tentu guru dituntut untuk dapat mengajarkan bahasa Indonesia yang mudah dicerna oleh siswa. Ternyata, mengajarkan bahasa Indonesia di SMP bukanlah sebuah pekerjaan yang mudah. Peneliti sering menerima keluhan teman-teman guru SMP yang merasa kesulitan melaksanakan proses belajar mengajar dengan Mata Pelajaran Bahasa Indonesia di SMP Negeri Kosgoro. Untuk itu dalam penelitian ini bertujuan mendeskripsikan kompetensi guru bahasa Indonesia di SMP Negeri Simpang Kosgoro Kabupaten Musi Rawas. Harapannya bisa menjadi masukan dalam pengembangan profesionalisme guru bahasa Indonesia khusunya di SMP Negeri Simpang Kosgoro Kabupaten Musi Rawas.

\section{METODE}

Metode penelitian yang digunakan yaitu metode deskriptif kuantitatif. Penelitian ini dilakukan di SMP Negeri Simpang Kosgoro Kabupaten Musi Rawas. Populasi dalam penelitian ini adalah guru bahasa Indonesia di SMP Negeri Simpang Kosgoro Kabupaten Musi Rawas berjumlah dua orang. Sedangkan sampel penelitian adalah seluruh anggota populasi yaitu berjumlah 2 orang guru bahasa Indonesia Kabupaten Musi Rawas. Populasi dalam penelitian ini adalah guru bahasa Indonesia di SMP Negeri Simpang Kosgoro, yaitu Bapak Drs. Abdullah dengan nilai 85 dan Ibu Nilai Kusumah, S.Pd.

Teknik pengumpulan data dalam penelitian ini menggunakan teknik observasi, lembar penilaian kinerja guru, dan kuesioner. Instrumen penelitian berupa lembar penilaian kinerja guru dari aspek pengajaran, publikasi, dan penunjang. Lembar penilaian kinerja guru ini berfungsi untuk mengukur kompetensi guru, yaitu kompetensi pedagogik, kompetensi kepribadian, kompetensi sosial, dan kompetensi profesional. Setiap aspek penilaian kinerja guru dengan skala 1-4, yang menunjukkan bahwa nilai 1 artinya kurang, nilai 2 artinya cukup, nilai 3 artinya baik, dan nilai 4 artinya sangat baik.

Teknik analisis data dilakukan dengan reduksi data penelitian, klasifikasi data, interpretasi data, dan kesimpulan tingkat kompetensi pedagogik, kompetensi kepribadian, kompetensi sosial, dan kompetensi profesional yang dimiliki guru bahasa Indonesia. Uji kebasahan data menggunakan membercheck terhadap hasil penilaian kinerja guru dari aspek pengajaran, publikasi, dan penunjang.

\section{HASIL}

Hasil penelitian dari data penilaian kinerja guru menunjukkan bahwa guru bahasa Indonesia di SMP Negeri Simpang Kosgoro, yaitu Bapak Drs. Abdullah dengan nilai 85 dan Ibu Nilai Kusumah, S.Pd. sudah sangat baik dengan nilai mencapai rentang 75-100 dengan nilai 4, baik dari segi kompetensi pedagogik, kompetensi kepribadian, kompetensi sosial, dan kompetensi profesional. Untuk lebih jelasnya, berikut hasil penelitian per kompetensi guru bahasa Indonesia di SMP Negeri Simpang Kosgoro.

1. Kompetensi Pedagogik

Pelaksanaan kompetensi kinerja guru bahasa Indonesia dalam pembelajaran bahasa Indoensia di SMP Negeri Simpang Kosgoro pada kompetensi pedagogik berdasarkan hasil analisis penelitian kedua orang guru yang menjadi subjek memiliki 
kinerja yang baik. Ketujuh kompetensi tersebut merupakan aspek-aspek mendasar yang harus dimiliki oleh setiap guru mata pelajaran dalam menjalankan profesinya. Keberhasilan penilaian pada ketujuh kompetensi ini wajib diperlukan. Persentasi penilaian kinerja setiap guru memenuhi kriteria baik. Kompetensi pedagogik dari tujuh aspek penilaian pada kedua orang guru bahasa Indonesia memiliki hasil yang baik. Dengan demikian, kedua orang guru tersebut pada kompetensi ini dinyatakan berhasil dan dapat melanjutkan ke proses selanjutnya untuk naik pangkat. Fungsi penilaian kinerja guru ini dalam memberikan penilaian legalitasnya sangat diperlukan oleh guru yang bersangkutan.

\section{Kompetensi Kepribadian}

Pelaksanaan kompetensi kinerja guru bahasa Indonesia dalam pembelajaran bahasa Indoensia di SMP Negeri Simpang Kosgoro pada kompetensi kepribadian berdasarkan hasil analisis penelitian kedua orang guru yang menjadi subjek memiliki kinerja yang baik. Ketiga kompetensi tersebut merupakan aspek-aspek hubungan antara guru dan siswa serta guru dengan teman sejawat dan warga sekolah yang harus dimiliki oleh setiap guru mata pelajaran dalam menjalankan profesinya. Keberhasilan penilaian pada ketiga kompetensi ini untuk melihat seberapa besar komunikasi antar guru dan siswa dalam pembelajaran. Persentasi penilaian kinerja setiap guru memenuhi kriteria baik. Kompetensi kepribadian yang memiliki tiga aspek penilaian pada kedua orang guru bahasa Indonesia memiliki hasil yang baik. Dengan demikian, kedua orang guru tersebut pada kompetensi ini dinyatakan berhasil dan dapat melanjutkan ke proses selanjutnya untuk naik pangkat. Fungsi penilaian kinerja guru ini dalam memberikan penilaian legalitasnya sangat dieprlukan oleh guru yang bersangkutan.

\section{Kompetensi Sosial}

Pelaksanaan kompetensi kinerja guru bahasa Indonesia dalam pembelajaran bahasa Indonesia di SMP Negeri Simpang Kosgoro pada kompetensi sosial berdasarkan hasil analisis penelitian kedua orang guru yang menjadi subjek memiliki kinerja yang baik. Kedua kompetensi tersebut merupakan aspek-aspek hubungan antara guru dan siswa serta guru dengan teman sejawat dan warga sekolah yang harus dimiliki oleh setiap guru mata pelajaran dalam menjalankan profesinya. Keberhasilan penilaian pada kedua kompetensi ini untuk melihat seberapa besar komunikasi antara guru dan siswa serta guru dengan teman sejawat dan warga sekolah dalam pembelajaran. Persentasi penilaian kinerja setiap guru memenuhi kriteria baik. Kompetensi sosial yang memiliki tiga aspek penilaian pada kedua orang guru bahasa Indonesia memiliki hasil yang baik. Dengan demikian, kedua orang guru tersebut pada kompetensi ini dinyatakan berhasil dan dapat melanjutkan ke proses selanjutnya untuk naik pangkat. Fungsi penilaian kierja guru ini dalam memberikan penilaian legalitasnya sangat diperlukan oleh guru yang bersangkutan.

4. Kompetensi Profesional

Pelaksanaan kompetensi kinerja guru bahasa Indonesia dalam pembelajaran bahasa Indoensia di SMP Negeri Simpang Kosgoro pada kompetensi profesional berdasarkan hasil analisis penelitian kedua orang guru yang menjadi subjek memiliki kinerja yang baik. Kedua kompetensi tersbut merupakan aspek-aspek hubungan antara guru dan siswa serta guru dengan teman sejawat dan warga sekolah yang harus dimiliki oleh setiap guru mata pelajaran dalam menjalankan profesinya. Keberhasilan penilaian pada kedua kompetensi ini untuk melihat seberapa besar komunikasi antar guru dan siswa dalam pembelajaran. Persentasi penilaian kinerja setiap guru memenuhi kriteria baik. Kompetensi kepribadian yang memiliki tiga aspek 
penilaian pada kedua orang guru bahasa Indonesia memiliki hasil yang baik. Dengan demikian, kedua orang guru tersebut pada kompetensi ini dinyatakan berhasil dan dapat melanjutkan ke proses selanjutnya untuk naik pangkat. Fungsi penilaian kierja guru ini dalam memberikan penilaian legalitasnya sangat diperlukan oleh guru yang bersangkutan.

\section{PEMBAHASAN}

Kompetensi guru bahasa Indonesia di SMP Negeri Simpang Kosgoro Kabupaten Musi Rawas dari hasil analisis data penilaian kinerja guru pada kriteria sangat baik. Kinerja guru yang baik ini mulai dari kompetensi pedagogik, kompetensi kepribadian, kompetensi sosial, dan kompetensi profesional. Hanya saja memang dari hasil observasi menunjukkan guru bahasa Indonesia pada kompetensi pedagogik masih belum begitu menguasai inovasi pembelajaran terbaru terutama terkait dengan teknologi yang sering disebut dengan pendekatan Technological Pedagogical Content Knowledge (TPACK). Pendekatan TPACK yaitu pendekatan tentang bagaimana memfasilitasi pembelajaran peserta didik dari konten tertentu melalui pendekatan pedagogik dan teknologi (Drummond \& Sweeney, 2016).

Selain itu, guru bahasa Indonesia masih mempunyai kelemahan dalam kompetensi kepribadian yang masih belum semua perilaku baiknya dijadikan teladan atau model oleh siswa dan teman sejawatnya. Kompetensi kepribadian ini sangat penting karena guru memiliki peran sebagai contoh dalam berperilaku. Hal ini sesuai dengan yang amat dalam Penjelasan Peraturan Pemerintah Nomor 19 Tahun 2005 tentang Standar Nasional Pendidikan dan menurut pendapat Supadi dkk. (2020) bahwa kompetensi kepribadian adalah kemampuan kepribadian yang: 1) mantap; 2) stabil; 3) dewasa; 4) arif dan bijaksana; 5) berwibawa; 6) berakhlak mulia; 7) menjadi teladan bagi peserta didik dan masyarakat; 8) mengevaluasi kinerja sendiri; dan 9) mengembangkan diri secara berkelanjutan.

Kompetensi profesional juga masih perlu ditingkatkan oleh guru bahasa Indonesia di SMP Negeri Simpang Kosgoro Kabupaten Musi Rawas. Terutama dalam penguasaan materi sesuai dengan kebutuhan peserta didik dan kualitas materi yang terbaru dari berbagai referensi yang terpercaya. Kompetensi profesional ini sebaiknya ke depan difasilitasi oleh kepala sekolah, misalnya dengan memberikan pelatihan-pelatihan yang terkait mencari sumber belajar berbasis teknologi. Kompetensi profesioanal menurut Ambarita (2017) dan Undang-Undang Nomor 14 Tahun 2005 adalah penguasaan materi pembelajaran secara luas dan mendalam, yang mencakup penguasaan materi kurikulum mata pelajaran di sekolah dan substansi keilmuan yang menaungi materinya, serta penguasaan terhadap struktur dan metodologi keilmuannya. Secara rinci, berikut kompetensi profesional yang harus dikuasai oleh guru: 1) menguasai materi, struktur, konsep, dan pola pikir keilmuan yang mendukung pelajaran yang dimampu; 2) mengusai standar kompentensi dan kompetensi dasar mata pelajaran/bidang pengembangan yang dimampu; 3) mengembangkan materi pembelajaran yang dimampu secara kreatif; 4) mengembangkan keprofesionalan secara berkelanjutan dengan melakukan tindakan reflektif; dan 5) memanfaatkan TIK untuk berkomunikasi dan mengembangakan diri.

Dari hasil penelitian ini diharapkan guru bahasa Indonesia lebih bisa meningkatkan kompetensi pedagogik, kompetensi kepribadian, kompetensi sosial, dan kompetensi profesionalnya. Langkah-langkah strategis untuk meningkatkan komptensi guru adalah bermusyawarah dengan kepala sekolah tentang program 
sekolah dalam meningkatkan kualitas guru khususnya guru bahasa Indonesia. Selain itu, bisa juga dengan guru bahasa Indonesia selalu merefleksi diri dengan melakukan kegiatan penelitian tindakan kelas sehingga mampu memahami permasalahan pembelajaran dan dapat melakukan tindakan yang terbaik dalam mengatasi permasalahan pembelajaran sebagai cerminan kualitas diri sendiri.

\section{KESIMPULAN DAN SARAN}

Hasil penelitian menunjukkan bahwa kompetensi guru bahasa Indonesia di SMP Negeri Simpang Kosgoro sudah sangat baik, dengan nilai mencapai rentang 75-100 dengan nilai 4, baik dari segi kompetensi pedagogik, kompetensi kepribadian, kompetensi sosial, dan kompetensi profesional. Hanya saja kompetensi pedagigik, kompetensi kepribadian, dan kompetensi profesional masih perlu ditingkatkan oleh guru bahasa Indonesia.

Saran dari hasil penelitian ini secara umum bagi organisasi atau lembaga pendidikan Dinas Pendidikan Nasional Kabupaten Musi Rawas khususnya di SMP Negeri Simpang Kosgoro terkait dengan penerapan penilaian kinerja individu. Saran tersebut adalah sebagai berikut: (1) Pemimpin organisasi dan seluruh pejabat penilai berkomitmen untuk mengimplementasikan PP Nomor 46 Tahun 2011 sesuai dengan ketentuan yang ditetapkan untuk memberikan hasil dan dampak yang lebih baik dan PP Nomor 46 tahun 2011 ini diharapkan penilaian prestasi kerja yang bermuara kepada pengembangan karier atau promosi, menentukan training, menentukan standar kompensasi, menentukan mutasi atau perpindahan pegawai, meningkatkan produktivitas dan tanggung jawab karyawan, meningkatkan motivasi pegawai. (2) Melaksanakan reward and punishment sebagai bagian dari pembinaan Pegawai Negeri Sipil di lingkungan Dinas Pendidikan Nasional Kabupaten Musi Rawas khususnya di SMP Negeri Simpang Kosgoro dengan demikian pengangkatan dalam jabatan harus didasarkan pada sistem prestasi kerja yang didasarkan atas penilaian objektif terhadap prestasi, kompetensi, dan pelatihan Pegawai Negeri Sipil di Dinas Pendidikan Nasional Kabupaten Musi Rawas khususnya di SMP Negeri Simpang Kosgoro. Dalam pembinaan kenaikan pangkat, disamping berdasarkan sistem prestasi kerja juga diperhatikan sistem karier, dengan mengacu dari peraturan Kementerian Pertahanan yang mensyaratkan untuk karier pangkat dan jabatan bisa mencapai maksimal yaitu jabatan struktural Eselon la yang dapat diduduki oleh PNS dan telah memenuhi persyaratan dengan pangkat Pembina Utama Madya Golongan Ruang IV/d.

Kemudian, (3) melalui hasil Penilaian Prestasi Kerja yang efektif maka akan terlihat berkembangnya organisasi Dinas Pendidikan Nasional Kabupaten Musi Rawas khususnya di SMP Negeri Simpang Kosgoro itu sendiri. Dari penilaian prestasi kerja dapat dilihat kinerja organisasi Dinas Pendidikan Nasional Kabupaten Musi Rawas khususnya di SMP Negeri Simpang Kosgoro yang dicerminkan oleh kinerja seluruh Pegawai Negeri Sipil di lingkungan Dinas Pendidikan Nasional Kabupaten Musi Rawas khususnya di SMP Negeri Simpang Kosgoro, sehingga perlu implementasi yang efektif dan juga faktor dari eksternal dari pemenuhan untuk standar akreditasi maka perlu melakukan validasi organisasi Dinas Pendidikan Nasional Kabupaten Musi Rawas khususnya di SMP Negeri Simpang Kosgoro. 


\section{DAFTAR PUSTAKA}

Ahmad, L. I. (2017). Konsep Penilaian Kinerja Guru dan Faktor yang Mempengaruhinya. Idaarah: Jurnal Manajemen Pendidikan, 1(1). doi:10.24252/idaarah.v1i1.4133

Ambarita, C. F. (2017). Kompetensi Profesional Guru SMA Kalam Kudus Medan. School Education Journal PGSD FIP UNIMED, 7(2), 164-169. doi:10.24114/sejpgsd.v7i2.6850

Ananda, L. J. (2017). Kajian Kompetensi dan Profesionalisasi Guru. School Education Journal PGSD FIP UNIMED, 7(2), 175-181. doi:10.24114/sejpgsd.v7i2.6852

Damanik, R. (2019). Hubungan Kompetensi Guru dengan Kinerja Guru. Jurnal Serunai Administrasi Pendidikan, 8(2). doi:10.37755/jsap.v8i2.170

Drummond, A., \& Sweeney, T. (2016). Can an objective measure of technological pedagogical content knowledge (TPACK) supplement existing TPACK measures? British Journal of Educational Technology, 48(4), 928-939. doi:10.1111/bjet.12473

Muspawi, M. (2020). Realisasi Kinerja Pengawas dalam Membina Kompetensi Profesional Guru. Jurnal Pendidikan Guru, 1(1). doi:10.47783/jurpendigu.v1i1.70

Noermanzah, N. (2015). Peran Dosen Bahasa dan Sastra Indonesia dalam Mempertahankan Bahasa Indonesia sebagai Alat Pemersatu Negara Kesatuan Republik Indonesia pada Era Globalisasi. In Prosiding Seminar Nasional Bulan Bahasa 2015. Unit Penerbitan FKIP Universitas Bengkulu, p. 275. http://repository.unib.ac.id/11133/

Peraturan Menteri Negara Pendayagunaan Aparatur Negara dan Reformasi Birokrasi Nomor 16 Tahun 2009 tentang Jabatan Fungsional Guru dan Angka Kreditnya.

Peraturan Pemerintah Republik Indonesia Nomor 19 Tahun 2005 tentang Standar Nasional Pendidikan.

Putri, A. D. K., \& Imaniyati, N. (2017). Pengembangan Profesi Guru dalam Meningkatkan Kinerja Guru. Jurnal Pendidikan Manajemen Perkantoran, 2(2), 93. doi:10.17509/jpm.v2i2.8109

Rivalina, R. (2016). Peran Guru Garis Depan dalam Mengembangkan Sekolah Efektif. Perspektif IImu Pendidikan, 30(2), 77. doi:10.21009/pip.302.2

Rusnailah, R. (2019). Hasil Penilaian Kinerja dan Capaian Kompetensi Guru (SMAN 2 Banjarmasin dan SMAN 13 Banjarmasin). Lentera: Jurnal Pendidikan, 14(1). doi:10.33654/jpl.v14i1.638 
Sagala, S. (2006). Konsep dan Makna Pembelajaran. Bandung: Alfabet.

Sarimaya, F. (2008). Sertifikasi Guru, Apa, Mengapa, dan Bagaimana? Bandung: Yrama Widya.

Supadi, Dewi W, Zulaikha S, Nuphanudin, Soraya E. (2020). Model Pengembangan Kompetensi Sosial dan Kepribadian Guru Berbasis Myers Briggs Type Indicator/MBTI berbasis Tekonologi Informasi. International Journal of Psychosocial Rehabilitation, 24(3), Available from: http://dx.doi.org/10.37200/ijpr/v24i3/pr200954

Susanti, R. (2013). Teknologi Pendidikan dan Peranannya dalam Transformasi Pendidikan. Jurnal Teknologi Pendidikan, 2(2). doi:10.32832/tek.pend.v2i2.448

Undang-Undang Republik Indonesia Nomor 14 Tahun 2005 tentang Guru dan Dosen.

Uno, H. B. (2009). Model Pembelajaran, Menciptakan Proses Belajar Mengajar yang Kreatif dan Efektif. Jakarta. Bumi Aksara. 